\title{
The Effectiveness of Academic Information System Utilization and Digital Literacy as the Efforts to Improve Students' Service Quality
}

\author{
Iswan (Corresponding Author), Herwina Bahar, Ismah, Suci Mulya Lestari \\ Universitas Muhammadiyah Jakarta, South Jakarta. Indonesia \\ E-mail: iswanfipumj@gmail.com
}

Received: December 13, 2021

Accepted: January 30, 2022 Published: February 1, 2021

doi:10.5296/jet.v9i2.19529

URL: https://doi.org/10.5296/jet.v9i2.19529

\begin{abstract}
The aim of this research is to measure the effectiveness of Academic Information Sytem and Digital Literacy utilized to serve the students of Faculty Education Muhammadiyah University of Jakarta. This research applied quantitative descriptive method which involved 90 students as respondents selected randomly. In collecting the data, a-5 Likert-scale questionnaire measuring the influence of digital literacy, the effectiveness of academic information system and students' attitudes toward service quality and satisfaction was used as the instrument in collecting the data. The data then being analyzed through $\mathrm{t}$-test and path analysis. The results of the study proved that those two variables were correlated positively and significantly in which the statistical analysis of t-test resulted $t_{\text {cal }}>\mathrm{T}_{\text {table }}=2.77>1.98$ and $\mathrm{P}_{\text {value }}<0.05=0.006<0.05$ ), while in the effort of improving service quality to the students, very high significant results were also obtained, proven by statistical test of (69.969>1.98 and $0.000<0.05)$. These findings were also strengthened by the statistical test of Academic Information System effectiveness and digital literacy which achieved the scores of $2.803>1.98$, and $0.005<0.05$.
\end{abstract}

Keywords: the effectiveness of Academic Information System, digital literacy, service quality

\section{Introduction}

The current advancing of technology develops very fast, in which various activities are conducted by utilizing various devices of technology. Thus, those activities can be conducted easier including in the field of education. Academic information service with online-based is expected to shorten the time in supporting academic needs of the students and the lecturers. Therefore, technology-based system, especially in Faculty of Education Muhammadiyah 
University of Jakarta, Indonesia, keeps being improved. A technology-based service to improve the effectiveness of online-based academic Information system called Academic Information Service network was built. This is an online-based academic system which can be accessed by all students, lecturers, and educators of the university. Academic Information Service is a solution to improve the quality service both to students and lecturers in which they use technology-based services to get various Academic Information independently by following the requirements managed by the university.

In this era, digital literacy becomes an urgent need for students, lecturers, and the society, especially the intellectuals. The advancement of technology, in line with digital literacy in utilizing modern technology based-devices, will ease the users and in this case, students, lecturers, and educators. Digital literacy is also part of United Nation long-term planning related to education and culture. In its roadmap (2015-2020), UNESCO shows its serious response to digital literacy as part of essential point for the future of education and becomes the basis of knowledge supported by integrated information and technology.

\section{Method of the Research}

This research study applied quantitative descriptive method in which 90 students were involved voluntarily and selected randomly. The research was carried out for about 5 months starting from December 2020 until April 2021. A set of questionnaires in the form of 5 Likert-scale to measure the influence of digital literacy, the effectiveness of academic information system and students' attitudes toward service quality and satisfaction distributed to those sample was used as the tool in collecting the data. In analyzing the data, the researchers applied t-test and path analysis.

\section{Review of the Literature}

The Effectiveness of Academic Information System Application In general, satisfaction is someone's feeling of both excited or disappointed exist by comparing the performance perceived by products, that person's expectations (Kotler: 2009). Satisfaction in this case is intended to happy feeling because the results of something fulfill the expectation or even more than expectation. The satisfaction time span was quite difficult to describe. That satisfaction might only apply currently, and the feelings can be changed in another time. Users' satisfaction in this study was measured from students' satisfactions who utilized online service through Academic Information System as the effort to fulfill the service to them and their academic needs.

\section{Application of Academic Administration System}

Information system is the collection of sub-system either physically or non-physically which are connected one to another and cooperate in a harmony to reach one goal, i.e. analyzing data to become benefitted information for the users. Information system is units of interrelated components which work together to collect, process, save and give a description of activities in a company. According to Mc. Known (2013:52), information system the integration of computer and user who analyses data modification into information and save those data and information. O'Brian in Yakub (2012:17), defined information system as a 
well-ordered combination of people, hardware and software, communication network, and data sources that collect, change, and spread the information in an organization. Information system in an organization connects the needs of daily data analysis transaction, supports operational, managerial and a strategy of an organization and also provides certain external parties with the reports needed.

Based on several definitions of information system above, it can be understood that system information is a combination of information technology and the persons who use that technology in doing their activities to support the operations of an institution/company and assit the management in taking decision. Through information system, the activities of institution/company can be carried out more effective and efficient.

\section{The Components of Information System}

Information system has several components in it. If one of the elements is not being fulfilled then that information system might not be settled. The integrated information system's components function to support and increase daily operation of the institution/company, besides providing information needs to solve problems and take management's decision. In relation with the components of information system, the components consist of: 1) Hardware; 2) Software; 3) Brainware; 4) Procedure; 5) Database; 6) Communication Network. Another group of the components are: 1) Data; 2) Brainware; 3) Activities; 4) Network; 5) Technology.

The explanation for each of those components are as follows: a. Hardware; covering physical devices such as computer, monitor, mouse and printer; b. Software; is a group of instruction which allows the hardware to do data processing; c. Brainware; All parties who are responsible as system owner, system user, system designer and system developer; $d$. Procedure; refers to a group of rules used to do data and expected output processing; e. Database; group of table, correlation, and other things related to data saving; $\mathrm{f}$. Communication Network; connecting system which allows resources to be used together or accessed by several users.

Another group of information system above is: Data: A description about things, events, activities, and transaction that have no meaning and no direct impact to the users or it is also called as a group of isolated raw facts. Brainware: All parties responsible for the development of information system, processing, and output usage. Activities: a group of rules or stages to make, use, process and analyze any information system or the output of that information system. Network; is a connection system which allows a resource to be used together either at the same time and place or different. Technology: Technology is a tool box in the information system used to receive input, run a model, save and access data, result and send output, and assist the control of overall system.

In its practice, all information system does not always cover those all components. For example, personal information system which only involves a user and a computer and does not always involve network facilities and communication, different from work-group information system which involves a number of people and computers, needs the facilities of network and communication. 


\section{The Application of Academic Information System}

Referring to various literature, as it was previously explained, it is known that information, communication and technology (ICT), literacy is the development of previous literature including internet literacy. Thus, it can be assumed that there is internet literacy in ICT literacy. In this research, internet literacy has indicators which are the same with ICT literacy since internet is also one of the components of ICT. Information Communication and Technology literacy began in $21^{\text {st }}$ century, formed from literacy where the researches and information communication through digital technology became important part in before that century (Katz. 2008:50). Further, according to Murray (2005:3), ICT literacy covering access, management, integration, evaluation, creation and communication of ICT knowledge for other people. That is why, the term of ICT means hardware, software application and technology network. Amara (2006:4), said in a survey report that ICT is not the ability of ICT teaching skill or used in teaching subjects, however, ICT skill is used to make sure that one of the paths in computer, desktop and various other ICT applications work well. Until now, there is no definition that can describe ICT literacy (Venhoof, 2005:5).

\section{Utilizing internet in Academic Information System}

Online based academic information system uses internet network that can be accessed by all communities in the environment of Muhammadiyah University of Jakarta. This system helps students and lecturers in giving excellent service through several rules managed by faculties. In this research study, the dimension of digital literacy used refers to the concepts of Mayes and Fawler which cover: digital competence and digital transformation. These dimensions this will give descriptions on how this academic information system applied in the university as a digital data based online application.

\section{Academic System Information}

Academic system information is a group of sub systems both physically and non-physically; soft-ware or hardware, which are interrelated, work cooperatively and systematically to reach one goal, namely analyzing data to become useful information. Based on the definition of information system above, it can be understood that an information system is a combination of information technology and the persons who use that technology in doing their activities, and to support the operations of an institution and assists management in taking decisions. Using academic information system in education will be more effective and efficient.

The application of academic information system refers to online-based information system and it is an appropriate decision to be applied by Faculty of Education Muhammadiyah University of Jakarta in running the academic administration activities. The main users of this application except lecturers are the students. This application contains all academic service activities for students starting from filling biodata of students and lecturers, study plan, scoring and graduates data which can be accessed through internet network by using laptop, computer and any other similar devices. 


\section{Dimensions of Digital Literacy}

According to Elena (2008), there are several dimensions of ICT literacy which move one dimension to another, as upgrading or improvement in ICT by connecting skills and competence as follows:

Table 1. Dimensions of ICT Literacy

\begin{tabular}{|c|c|c|}
\hline Dimension & Concept & Description \\
\hline Knowledge & $\begin{array}{l}\text { Basic } \\
\text { knowledge }\end{array}$ & $\begin{array}{l}\text { a. Ability to identify ICT } \\
\text { b. Knowing the development of ICT } \\
\text { c. Understanding the features of ICT } \\
\text { d. Familiar with the features of ICT }\end{array}$ \\
\hline Skill & $\begin{array}{l}\text { Technical } \\
\text { Skills }\end{array}$ & $\begin{array}{l}\text { a. Using the features of ICT application } \\
\text { b. Ability in accessing and searching a website } \\
\text { c. Able to make an account } \\
\text { d. Able to make database, manage, save and filter irrelevant } \\
\text { data } \\
\text { e. Ability to convert data } \\
\text { f. Able to make a user account }\end{array}$ \\
\hline Attitude & $\begin{array}{l}\text { Critical in } \\
\text { understanding } \\
\text { skills }\end{array}$ & $\begin{array}{l}\text { a. Technology changing in campus } \\
\text { b. The frequency of ICT usage gives impacts to academic } \\
\text { achievement } \\
\text { c. As tools to do research, manage, evaluate and communicate } \\
\text { the information } \\
\text { d. Level of ICT utilization }\end{array}$ \\
\hline
\end{tabular}

\section{Digital Literacy}

According to Paul Gilster (in Ministry of Education and Culture, 2017:7), digital literacy is defined as the ability to understand and use information in various forms either audio or visual from various widely sources which can be accessed through computer devices or digitalization. Thus, whatever type of information people gain from computer or digital is called Digital Literacy. UNESCO explains that the concept of digital literacy becomes crucial basis for the ability to understand devices of technology, information and communication. For example, in Information, Communication and Technology (ICT) Literacy, referring to 
technical skill or utilization and usage which possibly involves the society actively, in this case, the students as part of academic community, in line with the advancing of technology and digital-based academic services.

\section{Service Quality}

Goetsh and Davis cited in Tjiptono (2015:51), explain that quality is a dynamic condition related to products, service, humans, process and environment which fulfill or exceed the expectations. Or, it is meant that any condition which is suitable or exceeded our expectations. While quality services defined as anything focusing on the strengths of consumer necessity level as the main point of a service. In this study, quality service refers to the quality of academic service at Faculty of Education Muhammadiyah University of Jakarta, Indonesia.

\section{Research Findings}

\section{The Characteristics of Respondents}

The respondents involved in this research were 90 students of Faculty Education Muhammadiyah University of Jakarta, selected randomly. That total number was considered enough to be used as the representatives of the research subjects. The following table 2 presents the characteristics of those participants based on gender:

Table 2. Characteristics of Respondents Based on Gender

\begin{tabular}{|c|c|c|c|}
\hline \multirow[t]{4}{*}{ No } & Sex & Frequency Absolute & Percentage \\
\hline & Male & 21 & $23.33 \%$ \\
\hline & Female & 69 & $76.67 \%$ \\
\hline & Total & 90 & $100.0 \%$ \\
\hline
\end{tabular}

Source: Research Results from December 2020 until April 2021

It can be seen from the table above that, majority, the respondents participated in this study was female, i.e. 69 students (76.67\%), while male respondents were only 21 (23.33\%).

\section{The Analysis of Outer Model}

Standarized Loading Factor, one of PLS evaluation model in Outer Model is standardized loading factor applied to measure the accuracy of indicator. According to Latan and Ghozali (2014), the higher one indicator is, the higher its validity will be, and the ideal value of loading factor is $\geq 0.70$. 


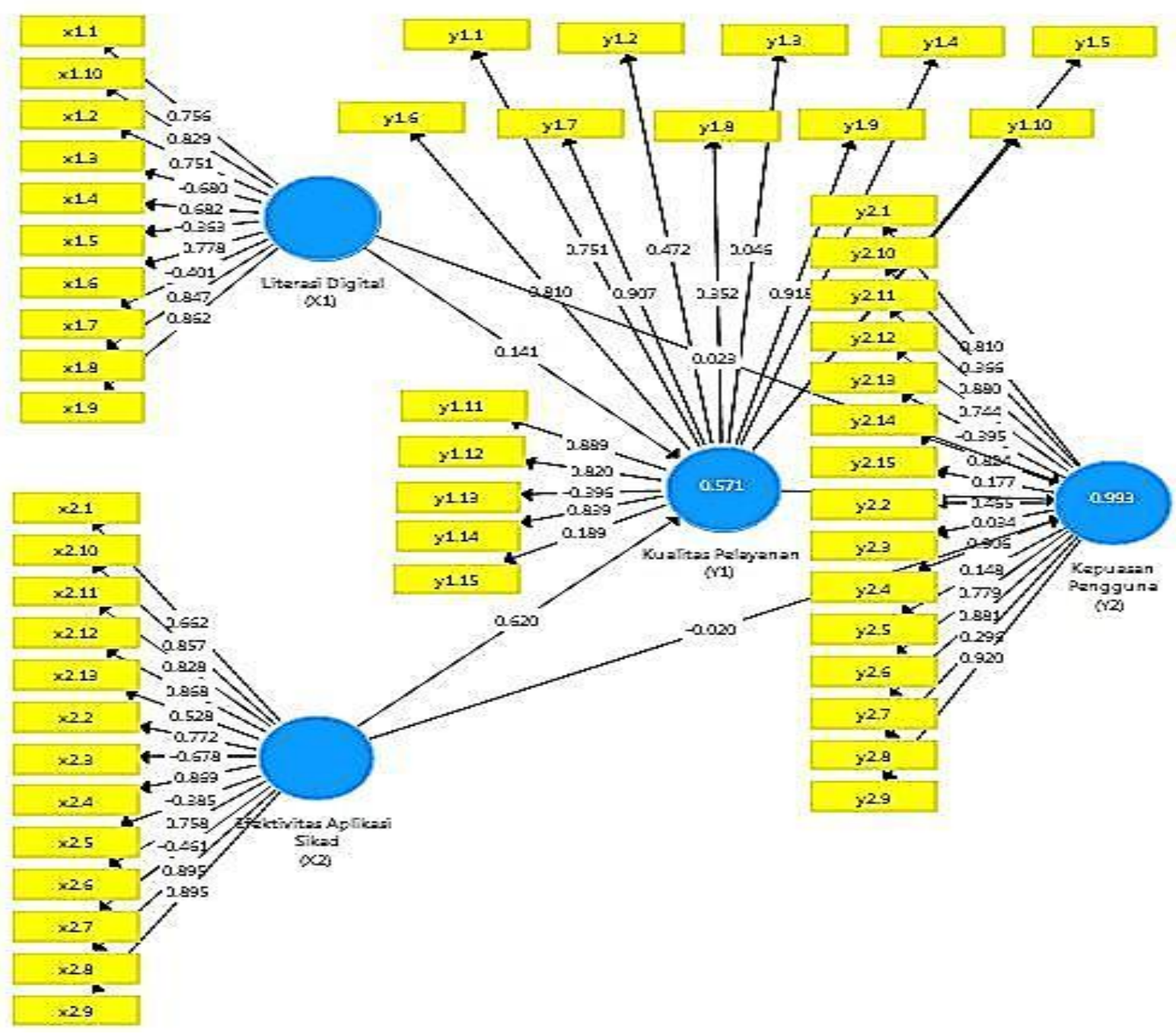

Picture 1. Standarized Loading Factor

Source: Primary data analyzed by PLS 3.0 


\section{I Macrothink}

Journal of Education and Training

ISSN 2330-9709

2022, Vol. 9, No. 2

Table 3. Outer Loading

\begin{tabular}{|c|c|c|c|}
\hline Variable & Indcator & Outer Loading PLS & Remarks \\
\hline \multirow{10}{*}{ Digital Literacy $\left(\mathrm{X}_{1}\right)$} & $\mathrm{X}_{1.1}$ & 0.756 & Valid \\
\hline & $\mathrm{X}_{1.2}$ & 0.751 & Valid \\
\hline & $\mathrm{X}_{1} .3$ & -0.680 & Invalid \\
\hline & $\mathrm{X}_{1} .4$ & 0.682 & Invalid \\
\hline & $X_{1} .5$ & -0.363 & Invalid \\
\hline & $X_{1} .6$ & 0.778 & Valid \\
\hline & $X_{1.7}$ & -0.401 & Invalid \\
\hline & $\mathrm{X}_{1} .8$ & 0.847 & Valid \\
\hline & $\mathrm{X}_{1} .9$ & 0.862 & Valid \\
\hline & $\mathrm{X}_{1} .10$ & 0.829 & Valid \\
\hline \multirow{13}{*}{$\begin{array}{c}\text { The Effectiveness of } \\
\text { Academic System Information } \\
\left(\mathrm{X}_{2}\right)\end{array}$} & $\mathrm{X}_{2.1}$ & 0.662 & Invalid \\
\hline & $\mathrm{X}_{2.2}$ & 0.772 & Valid \\
\hline & $X_{2.3}$ & -0.678 & Invalid \\
\hline & $\mathrm{X}_{2.4}$ & 0.869 & Valid \\
\hline & $X_{2.5}$ & -0.385 & Invalid \\
\hline & $\mathrm{X}_{2} .6$ & 0.758 & Valid \\
\hline & $X_{2.7}$ & -0.461 & Invalid \\
\hline & $\mathrm{X}_{2.8}$ & 0.895 & Valid \\
\hline & $\mathrm{X}_{2} .9$ & 0.895 & Valid \\
\hline & $X_{2.10}$ & 0.857 & Valid \\
\hline & $\mathrm{X}_{2.11}$ & 0.828 & Valid \\
\hline & $X_{2.12}$ & 0.868 & Valid \\
\hline & $\mathrm{X}_{2.13}$ & 0.528 & Invalid \\
\hline \multirow{15}{*}{$\begin{array}{l}\text { The Quality of Service } \\
\left(\mathrm{Y}_{1}\right)\end{array}$} & $\mathrm{Y}_{1.1}$ & 0.751 & Valid \\
\hline & $\mathrm{Y}_{1.2}$ & 0.472 & Invalid \\
\hline & $\mathrm{Y}_{1.3}$ & 0.046 & Invalid \\
\hline & $Y_{1.4}$ & 0.905 & Valid \\
\hline & $Y_{1.5}$ & 0.171 & Invalid \\
\hline & $Y_{1.6}$ & 0.810 & Valid \\
\hline & $Y_{1.7}$ & 0.907 & Valid \\
\hline & $Y_{1.8}$ & 0.352 & Invalid \\
\hline & $Y_{1} .9$ & 0.918 & Valid \\
\hline & $\mathrm{Y}_{1.10}$ & 0.272 & Invalid \\
\hline & $Y_{1.11}$ & 0.889 & Valid \\
\hline & $Y_{1.12}$ & 0.820 & Valid \\
\hline & $Y_{1.13}$ & -0.396 & Invalid \\
\hline & $Y_{1.14}$ & 0.839 & Valid \\
\hline & $\begin{array}{c}\mathrm{Y}_{1.15} \\
\text { Indicator }\end{array}$ & $\begin{array}{c}0.189 \\
\text { Outer Loading PLS }\end{array}$ & $\begin{array}{l}\text { Invalid } \\
\text { Remarks }\end{array}$ \\
\hline \multirow{15}{*}{$\begin{array}{l}\text { Users' Satisfaction } \\
\qquad\left(\mathrm{Y}_{2}\right)\end{array}$} & $\mathrm{Y}_{2.1}$ & 0.810 & Valid \\
\hline & $\mathrm{Y}_{2.2}$ & 0.465 & Invalid \\
\hline & $\mathrm{Y}_{2.3}$ & 0.034 & Invalid \\
\hline & $\mathrm{Y}_{2.4}$ & 0.906 & Valid \\
\hline & $\mathrm{Y}_{2.5}$ & 0.148 & Invalid \\
\hline & $\mathrm{Y}_{2.6}$ & 0.779 & Valid \\
\hline & $\mathrm{Y}_{2.7}$ & 0.881 & Valid \\
\hline & $\mathrm{Y}_{2.8}$ & 0.296 & Invalid \\
\hline & $\mathrm{Y}_{2.9}$ & 0.920 & Valid \\
\hline & $\mathrm{Y}_{2.10}$ & 0.366 & Invalid \\
\hline & $\mathrm{Y}_{2.11}$ & 0.880 & Valid \\
\hline & $\mathrm{Y}_{2.12}$ & 0.744 & Valid \\
\hline & $\mathrm{Y}_{2.13}$ & -0.395 & Invalid \\
\hline & $\mathrm{Y}_{2.14}$ & 0.824 & Valid \\
\hline & $\mathrm{Y}_{2.15}$ & 0.177 & Invalid \\
\hline
\end{tabular}

Source: Primary data analyzed by PLS 3.0 


\section{Macrothink}

Based on the initial results of outer loading by using the application of PLS, revealed that not all indicators reached the value of more than 0.7 hence this can be said that not all of those indicators were significant. Therefore, there were several indicators removed from the construct, namely: $\mathrm{X}_{1.3}, \mathrm{X}_{1} .4, \mathrm{X} 1.5, \mathrm{X}_{1} .7, \mathrm{X}_{2} .1, \mathrm{X}_{2.3}, \mathrm{X}_{2.5}, \mathrm{X}_{2.7}, \mathrm{X}_{2.13}, \mathrm{Y}_{1.2}, \mathrm{Y}_{1.3}, \mathrm{Y}_{1.5}, \mathrm{Y}_{1.8}, \mathrm{Y}_{1.10}$ $\mathrm{Y}_{1.13}, \mathrm{Y}_{1.15}, \mathrm{Y}_{2.2}, \mathrm{Y}_{2.3}, \mathrm{Y}_{2.5}, \mathrm{Y}_{2.8}, \mathrm{Y}_{2.10}, \mathrm{Y}_{2.13}$, dan $\mathrm{Y}_{2.15 .}$

Because those indicators achieved the smallest score analyzed by outer loading, hence, after dropping several indicators mentioned above, the following picture 2 presents the result of Standardized Loading Factor:

After dropping indicators with smallest values

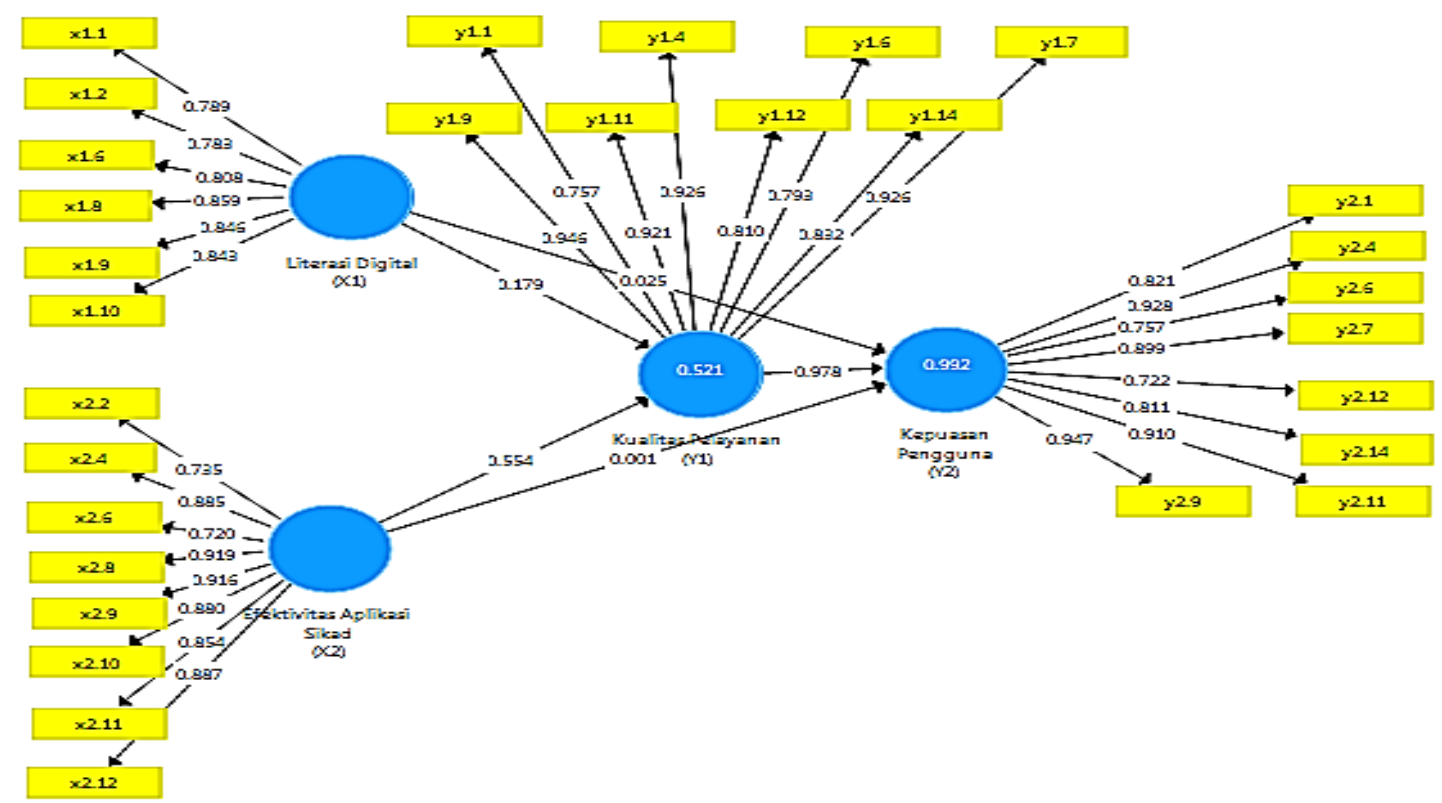

Gambar 2. Standarized Loading Factor

Source: Primary data analyzed by PLS 3.0

Picture above is the presentation of decreasing data sample in which as it was previously explained, several indicators only hit lower than 0.70 as the ideal loading factor.

\section{Average Variance Extracted (AVE)}

According to Grefen and Straub (2005), dicrimation validity can also be seen from the value of Average Variance Extracted (AVE), this AVE score is used to test square root of each AVE to measure if the correlation is bigger than each latent construct. Wijayanto (2008), stated that the minimum AVE score to confirm that the reability has been achieved is 0.50 , showing that indicator value has higher average error level as presented in the below table 4 . 
Table 4. Average Variance Extracted (AVE)

\begin{tabular}{c|c|c}
\hline Variable & $\begin{array}{c}\text { Average Variance } \\
\text { Extracted (AVE) }\end{array}$ & Remarks \\
\hline Digital Literacy $\left(\mathrm{X}_{1}\right)$ & 0.727 & $\begin{array}{c}\text { Convergent Validity is } \\
\text { adequate }\end{array}$ \\
\hline $\begin{array}{c}\text { The Effectiveness of Academic } \\
\text { System Information (X) }\end{array}$ & 0.727 & $\begin{array}{c}\text { Convergent Validity is } \\
\text { adequate }\end{array}$ \\
\hline $\begin{array}{c}\text { Service Quality } \\
\left(\mathrm{Y}_{1}\right)\end{array}$ & 0.751 & $\begin{array}{c}\text { Convergent Validity is } \\
\text { adequate }\end{array}$ \\
\hline $\begin{array}{c}\text { Users Satisfaction } \\
\left(\mathrm{Y}_{2}\right)\end{array}$ & 0.675 & $\begin{array}{c}\text { Convergent Validity is } \\
\text { adequate }\end{array}$ \\
\hline
\end{tabular}

Source: Research Results from December 2020 until April 2021

It can be seen from the table above that all value of AVE $>0.5$, this showed that all indicators wee able to explain each of their contract well (valid). Varibale $X_{1}$ (Digital Literacy) had AVE of 0.727 with adequate convergent validity. Quality service as $\mathrm{Y}_{2}$ reached a bit lower of AVE compared to $\mathrm{X}_{1}$ and $\mathrm{X}_{2}$, namely 0.751 , also with the remark that convergent validity is adequate. While another one is variable $\mathrm{Y}_{2}$ (Users' Satisfaction) which achieved AVE much lower that the other 3 , that was 0.675 , however this number is still higher that ideal standard value of 0.5 , hence, it was also confirmed as having adequate convergent validity.

\section{Cronbach's Alpha}

According to Hair, et.al. (2010), Cronbach's Alpha is a readability measure that is around zero to one. While Eisingerich and Ribera (2010) added that the readability measure level of minimum Cronbach's Aplha is 0.70. Cronbach's Alpha resulted from the analysis of this research data are presented in the following table 5:

Table 5. Cronbach's Alpha

\begin{tabular}{c|c|c|c|c}
\hline Varia & $\begin{array}{c}\text { Cronbach's } \\
\text { Alpha }\end{array}$ & rho_A & $\begin{array}{c}\text { Composite } \\
\text { Reability }\end{array}$ & Remarks \\
\hline $\begin{array}{c}\text { Digital Literacy }\left(\mathrm{X}_{1}\right) \\
\begin{array}{c}\text { Effectives of Academic System Information } \\
\text { Application }\left(\mathrm{X}_{2}\right)\end{array}\end{array} 0^{0.945}$ & 0.945 & 0.951 & 0.955 & Reliable \\
\hline $\begin{array}{c}\text { Service Quality } \\
\left(\mathrm{Y}_{1}\right)\end{array}$ & 0.951 & 0.956 & 0.960 & Reliable \\
\hline $\begin{array}{c}\text { Users' Satisfaction } \\
\left(\mathrm{Y}_{2}\right)\end{array}$ & 0.904 & 0.909 & 0.926 & Reliable \\
\hline
\end{tabular}

Source: Research Results from December 2020 until April 2021

From that table, it can be clearly seen that Cronbach's Alpha of all variables exceeded the 
minimum limit of 0.70 . Besides, rho_A at table was also bigger than the existed composite reliability. Therefore, the analysis of all 4 variables of this study confirmed that they were all reliable since their composite reliability was more than 0.70 in which this data were permanent and do not change over a period of time.

\section{Discriminant Validity}

Discriminant Validity is used to compare square root scores of Average Variance Extracted (AVE) of each construct with the correlation between other constructs in that model. Latand and Ghozali (2014) argued that a model has good Discriminant Validity if the correlation values of each construct with other constructs are good. The way to test it is if square root of Average Variance Extracted (AVE) bigger than the correlation with another all contructs then it is called that it has good Discriminant Validity. The recommended measurement score should be higher than 0.50 .

Table 6. AVE and SR AVE Scores

\begin{tabular}{c|c|c}
\hline Variable & $\begin{array}{c}\text { Average Variance } \\
\text { Extracted (AVE) }\end{array}$ & $\begin{array}{c}\text { Square Root Of Average Variance } \\
\text { Extracted (SR AVE) }\end{array}$ \\
\hline Digital Literacy $\left(\mathrm{X}_{1}\right)$ & 0.727 & 0.528 \\
\hline $\begin{array}{c}\text { Effectiveness of Academic System } \\
\text { Information }\left(\mathrm{X}_{2}\right)\end{array}$ & 0.727 & 0.528 \\
\hline Service Quality $\left(\mathrm{Y}_{1}\right)$ & 0.751 & 0.564 \\
\hline Users' Satisfaction $\left(\mathrm{Y}_{2}\right)$ & 0.675 & 0.455 \\
\hline
\end{tabular}

Source: Research Results from December 2020 until April 2021

Referring to the previous explanation stated that good discriminant validity measurement result must be higher than 0.50 , then it can be seen from table 6 above that Square Root of Average Variance Extracted ( $S R A V E$ ) of all variables fulfilled this requirement in which the score gained by each variable was above 0.50 . The variable of 'Digital Literacy' $\left(\mathrm{X}_{1}\right)$ had SR AVE in the amount of sebesar 0.528, variable of 'The Effectiveness of Academic System Information $\left(\mathrm{X}_{2}\right)$ reached SR AVE of 0.528. Meanwhile, variable of 'Service Quality' $\left(\mathrm{Y}_{1}\right)$ hit SR AVE of 0.564, and the other one variable of 'Users' Satisfaction' achieved 0.455 of SR AVE. Comparing to the other three variables, this last obtained the smallest score, however, if that value of 0.455 was evened, the result still fulfilled the minimum of good discriminant validity measurement, i.e. higher than 0.50 ., but not really significant. However, even this variable was not significant it did not influence the results of users' satisfaction in this research study.

\section{The Analysis of Inner Model - Goodness of Fit}

$\mathrm{R}^{2}$ (Coefficient Determinant) Value, According to Ghozali (2014), coefficient of determination measures the ability of a model in explaining dependent variables. The indicators of its measurement are as follows: The Value of $\mathrm{R}^{2}>0.19$ is categorized as 'weak'. The Value of $\mathrm{R}^{2}$ between $0.20-0.33$ is categorized as 'moderate'. The Value of $\mathrm{R}^{2}$ between 
0.34-0.67 is categorized as 'substantial'. The Value of $\mathrm{R}^{2}>0.67$ is categorized as 'strong' Referring to the analysis of the results, coefficient determinant of the data found are presented in table 7 below:

Tabel 7. $\mathrm{R}^{2}$ Value (Coefficient Determinant)

\begin{tabular}{c|c|c|c}
\hline Variable & R Square & R Square Adjusted & Remarks \\
\hline Service Quality $\left(\mathrm{Y}_{1}\right)$ & 0.521 & 0.510 & Moderate \\
\hline Users Satisfaction $\left(\mathrm{Y}_{2}\right)$ & 0.992 & 0.992 & Strong \\
\hline
\end{tabular}

Source: Research Results from December 2020 until April 2021

Based on table 7 above, it can be explained that the result of $\mathrm{R}^{2}$ for User Satisfaction variable $\left(\mathrm{Y}_{2}\right)$ was very strong since it reached higher Rsquare and Adjusted than 0.67 that was 0.992. While Service Quality variable ( $\left.\mathrm{Y}_{1}\right)$ hit Rsquare of 0.521 and Adjusted of 0.510 , which were lower than $\mathrm{R}^{2}$, hence it was categorized into 'moderate' level. Therefore, coefficient determinant value of Service Quality $\left(\mathrm{Y}_{1}\right)$ was predicted as $51.0 \%$ affected by Digital Literacy and Effectiveness of Academic Information System Application, meanwhile, the rests of $49.0 \%$ was influenced by other variables outside of this research. Further, the variable of User Satisfaction $\left(\mathrm{Y}_{2}\right)$ was predicted as $99.2 \%$ influenced by both variables of Digital Literacy and Effectiveness of Academic Information System Application, while the other $0.8 \%$ was affected by other variables outside of this study.

\section{The Value of $\mathrm{Q}_{2}$ (Predictive Relevance)}

Testing inner model can be by calculating the value of $\mathrm{Q}^{2}$ (predictive relevance). Ghozali (2014) explained that $\mathrm{Q}^{2}$ value can be used to measure how good the value of the observation resulted from model and its parameter estimation. The value of $\mathrm{Q}^{2}>0$ shows that a model has predictive relevance, and vice versa, if the value of $\mathrm{Q}^{2} \leq 0$, it indicates that a model has less predictive relevance. In order to calculate $\mathrm{Q}^{2}$ the following formulas can be applied:

$\mathrm{Q}^{2}=1-\left(1-\mathrm{R} 1^{2}\right)\left(1-\mathrm{R} 2^{2}\right) \ldots\left(1-\mathrm{Rp}^{2}\right)$

$\mathrm{Q}^{2}=1-\left(1-0.521^{2}\right)\left(1-0.992^{2}\right)$

$\mathrm{Q}^{2}=1-(1-0.271)(1-0.984)$

$\mathrm{Q}^{2}=1-(0.729)(0.016)$

$\mathrm{Q}^{2}=1-0.011$

$\mathrm{Q}^{2}=0.989$

If the value of $\mathrm{Q}^{2}$ is higher than 0 (null), or almost approach 1 (one), it means a model has predictive relevance or it is called relevant model value. Therefore, $\mathrm{Q}^{2}$ in determinant coefficient of variable $\mathrm{Y}_{1}$ (service quality) and $\mathrm{Y}_{2}$ (user satisfaction) which hit the higher value than 0, i.e. 0.989 , said as a research or a model which has predictive relevance in Inner Model test. 


\section{Goodness of Fit (GoF)}

In a Fit test using the application of Smart PLS, there are several measurements such as Standardized Root Mean Square Residual (SRMR), exact fit criteria d_ULS and d_G, NFI, $\mathrm{Chi}^{2}$ and RMS_Theta. SRMR is defined as the differences between observed correlation and implicit matrix correlation model. For this criterion, the value of SRMR was $<0.10$ or 0.8 , hence it was considered 'Fit', this SMSR was used to avoid mis-specification of model. Meanwhile, the value of $\mathrm{Chi}^{2}$ used in appropriateness and fit tests with the significance value of $\mathrm{p} \geq 0.05$.

SEM literature proposed fit normed index to calculate the value of $\mathrm{Chi}^{2}$ from proposed model and compare it with meaningful standard. NFI applies $\mathrm{Chi}^{2}$ value of null model as the indicator. Thus, NFI is then defined as 1 , minus $\mathrm{Chi}^{2}$ value of proposing model and then divided by null model $\mathrm{Chi}^{2}$ value. As the result, NFI will be between 0 and 1 . The closer NFI to 1 the better, and the NFI value above 0.9 usually indicates acceptable fit.

Table 8. Fit Model

\begin{tabular}{|c|c|c|}
\hline & Saturated Model & Estimated Model \\
\hline SRMR & 0.117 & 0.117 \\
\hline d_ULS & 6.385 & 6.385 \\
\hline Chi-Square & $66,710.287$ & $66,710.287$ \\
\hline NFI & 0.729 & 0.729 \\
\hline
\end{tabular}

Based on table 8 above, it can be seen that the value of SRMR was 0.117 with the criterion of $\mathrm{SRMR}<0.10$ or $0.8, \mathrm{Chi}^{2}$ hit the number of 66.710 .287 and NFI gained was 0.729 or almost approached 1, therefore, the model in this research was assumed as fulfilling the criterion of Goodness of Fit, or in other words the model called as FIT.

\section{Hypothesis Tests}

The hypothesis tests in this research were based on the guidance and the results of primary data sources from PLS program. Table 9 below presents the results of primary through PLS program. 
Table 9. Path Coefisien Inner Model

\begin{tabular}{|c|c|c|c|c|c|}
\hline & $\begin{array}{l}\text { Original } \\
\text { Sample } \\
\text { (O) }\end{array}$ & $\begin{array}{l}\text { Sample } \\
\text { Mean } \\
\text { (M) }\end{array}$ & $\begin{array}{l}\text { Standard } \\
\text { Deviation } \\
\text { (STDEV) }\end{array}$ & $\begin{array}{l}\text { TStatistics } \\
(|\mathrm{O} / \mathrm{STDEV}|)\end{array}$ & $\mathrm{P}_{\text {values }}$ \\
\hline $\begin{array}{llll}\mathrm{X}_{1 \_}(\text {Digital } & \text { Literacy) } & -> & \mathrm{Y}_{1 \_}(\text {Service } \\
\text { Quality) } & & & \end{array}$ & 0.179 & 0.206 & 0.186 & 0.964 & 0.336 \\
\hline $\begin{array}{llll}\mathrm{X}_{1 \_}(\text {Digital } & \text { Literacy) } & \rightarrow & \mathrm{Y}_{2} \text { (User } \\
\text { Satisfaction) } & & & \end{array}$ & 0.025 & 0.022 & 0.018 & 1.413 & 0.158 \\
\hline $\begin{array}{l}\mathrm{X}_{2 \_}(\text {Effectiveness of Academic System } \\
\text { Information) }->Y_{1} \text { (Service Quality) }\end{array}$ & 0.554 & 0.530 & 0.200 & 2.776 & 0.006 \\
\hline $\begin{array}{l}\mathrm{X}_{2}(\text { Effectiveness of Academic System } \\
\text { Information)-> } \mathrm{Y}_{2} \text { (User Satisfaction) }\end{array}$ & 0.001 & 0.005 & 0.029 & 0.027 & 0.978 \\
\hline $\begin{array}{llll}Y_{1 \_}(\text {Service } \\
\text { Satisfaction) }\end{array} \quad$ Quality) $\quad->\quad Y_{2 \_(U s e r}$ & 0.978 & 0.976 & 0.014 & 69.969 & 0.000 \\
\hline
\end{tabular}

Source: Research Results from December 2020 until April 2021

The calculation of hypothesis test based on sample and t-table explains that the standard value of table with 90 numbers of sample is 1.98 with two tailed-test $(\alpha=0.05)$. The calculation of significance influence refers to the explanation of $t_{\text {statistics }}>t_{\text {table }}(1.98)$ and $\mathrm{P}_{\text {value }}<\alpha(0.05)$. While for the insignificant effect is referred to the explanation of $t_{\text {statistics }}<\mathrm{T}_{\text {table }}(1.98)$ and $\mathrm{P}_{\text {value }}>\alpha(0.05)$. However, if the insignificant one reached positive result (not negative), then the research will be accepted. Based on the analysis of direct influences between varibales by using PLS program version 3.0, the findings can be explained as follows:

\section{Hypothesis Test 1: The Influence of Digital Literacy on Service Quality}

The correlation coefficient parameter for Digital Literacy variable $\left(\mathrm{X}_{1}\right)$ with Service Quality ( $\mathrm{Y}_{1}$ ) was 0.179 , with tstatistics of 0.964 and $\mathrm{P}_{\text {value }}$ of 0.336 . These results described that if the value of Digital Literacy increases 1 point then the the increasing value of Service Quality would be 0.179 point. With statistical value of $0.964<1.98$ and $P_{\text {value }}$ of $0.336>0.05$, indicated that the correlation of Digital Literacy $\left(\mathrm{X}_{1}\right)$ with Service Quality $\left(\mathrm{Y}_{1}\right)$ was positively direct but insignificant.

\section{Hypothesis Test 2: The Influence of Digital Literacy on User Satisfaction}

Parameter coefficient of Digital Literacy $\left(\mathrm{X}_{1}\right)$ correlated with User Satisfaction $\left(\mathrm{Y}_{2}\right)$ was 0.025. This result showed that if Digital Literacy increases 1 point then the one correlated with User Satisfaction was 0.025 point. While for the $\mathrm{t}$-statistics of $1.413<1.98$ and $\mathrm{P}$ value of $0.158>0.05$ indicated that Digital Literacy directly influenced User Satisfaction in positive but not significant.

\section{Hypothesis Test 3: The Influence of the Effectiveness of Academic Information System Application towards Service Quality}

The coefficient parameter of effectiveness of academic information system, application variable $\left(\mathrm{X}_{2}\right)$ towards Service Quality $\left(\mathrm{Y}_{1}\right)$ was 0.554 . It can be described that if the 
effectiveness of Academic System Information Application increases 1 point then the influence towards Service Quality was 0.554 point. While t-statistics of 2.776>1.98 and Pvalue of $0.006<0.05$ indicated that Academic Information System Application Effectiveness $\left(\mathrm{X}_{2}\right)$ gave direct influence to Service Quality $\left(\mathrm{Y}_{1}\right)$ both positively and significantly.

\section{Hypothesis Test 4: The Influence of Academic System Information Application towards User Satisfaction}

Coefficient parameter of Academic Information System Application Effectiveness $\left(\mathrm{X}_{2}\right)$ towards User Satisfaction $\left(\mathrm{Y}_{2}\right)$ was 0.001 . This can be defined that if the value of Academic Information System Application Effectiveness increases 1 point then the one which influenced User Satisfaction was 0.001 point. The t-statistics value of $0.027<1.98$ and $\mathrm{P}_{\text {value }}$ of $0.978>0.05$ explained that Academic Information System Application Effectiveness $\left(\mathrm{X}_{2}\right)$ direct positively affected User Satisfaction $\left(\mathrm{Y}_{2}\right)$ but not significant.

\section{Hypothesis Test 5: Influence of Service Quality to Users' Satisfaction}

The coefficient parameter value of Service Quality ( $\left.\mathrm{Y}_{1}\right)$ correlated with User Satisfaction reached the score of 0.978 . This result can be explained that if the score of Service Quality increased 1 point then the one which influenced User Satisfaction was 0.978 point. T-statistics of 69.969>1.98 and $\mathrm{P}_{\text {value }}$ of $0.000<0.05$ described direct influence of Service Quality (Y) which correlated with User Satisfaction $\left(\mathrm{Y}_{2}\right)$ positively and significantly. Therefore, from the hypothesis tests above, it can be concluded that Digital Literacy $\left(\mathrm{X}_{1}\right)$ correlated with Service Quality $\left(\mathrm{Y}_{1}\right)$ in positive but insignificant since the value was low.

Hypothesis test of Digital Literacy $\left(\mathrm{X}_{1}\right)$ with User Satisfaction $\left(\mathrm{Y}_{2}\right)$ was also positive with insignificant result of previous hypothesis test. The effectiveness of Academic Information System Application $\left(\mathrm{X}_{2}\right)$ correlated with Service Quality $\left(\mathrm{Y}_{1}\right)$ positively and very significant because the value was high. For the next hypothesis test, the effectiveness of Academic Information System Application $\left(\mathrm{X}_{2}\right)$ correlated with User Satisfaction $\left(\mathrm{Y}_{2}\right)$ also in positive result but not significant as the influence of $\mathrm{X}_{2}$ to $\mathrm{Y}_{1}$ previously. The result of the last hypothesis test was between Service Quality ( $\left.\mathrm{Y}_{1}\right)$ and User Satisfaction $\left(\mathrm{Y}_{2}\right)$ was proven as positive and very significant since the Value was high.

\section{The Analysis of Indirect Effect thorugh PLS}

Table 10. Indirect Effect among variable through PLS Method

\begin{tabular}{|c|c|c|c|c|c|c|}
\hline & & $\begin{array}{c}\text { Original } \\
\text { Sample }(O)\end{array}$ & $\begin{array}{l}\text { Sample } \\
\text { Mean } \\
(\mathrm{M})\end{array}$ & $\begin{array}{l}\text { Standard } \\
\text { Deviation } \\
\text { (STDEV) }\end{array}$ & $\begin{array}{l}\text { T Statistics } \\
(|\mathrm{O} / \mathrm{STDEV}|)\end{array}$ & $P_{\text {values }}$ \\
\hline $\begin{array}{l}\mathrm{X}_{1 \_(\text {Digital Literacy)-> }} \\
\text { Quality)-> } \\
\mathrm{Y}_{2 \_}(\text {User Satisfaction }\end{array}$ & $\mathrm{Y}_{1 \_}($Service & 0.542 & 0.517 & 0.193 & 2.803 & 0.005 \\
\hline $\begin{array}{l}\mathrm{X}_{2 \_}(\text {Effectives of Academic } \\
\text { System)-> Y Y }{ }_{1} \text { (Service } \\
\mathrm{Y}_{2 \_} \text {(User Satisfaction) }\end{array}$ & $\begin{array}{l}\text { Information } \\
\text { Quality)-> }\end{array}$ & 0.175 & 0.202 & 0.182 & 0.964 & 0.335 \\
\hline
\end{tabular}


Source: Research Results from December 2020 until April 2021

Indirect Effect of Digital Literacy $\left(\mathrm{X}_{1}\right)$ correlated with User Satisfaction $\left(\mathrm{Y}_{2}\right)$ through Service Quality $\left(\mathrm{Y}_{1}\right)$ as mediator. Based on the analysis result presented in table 4.9 by using PLS method, it was known that the indirect effect of Digital Literacy $\left(\mathrm{X}_{1}\right)$ correlated with User Satisfaction $\left(\mathrm{Y}_{2}\right)$ through Service Quality $\left(\mathrm{Y}_{1}\right)$ as mediator gained the value of $\mathrm{r}=0.542$, $t_{c a l}=2.803$, and $P_{\text {value }}=0.005$. Thus, it can be said that the indirect effect of Digital Literacy towards User Satisfaction through Service Quality was proven as significant because $t_{\text {cal }}$ $(2.803)>\mathrm{T}_{\text {table }}(1.98$, achieved from $\mathrm{n}=90, \alpha=0.05)$ and $\mathrm{P}_{\text {value }}(0.005)<\alpha(0.05)$.

Indirect effect of Academic Information System Application Effectivenss $\left(\mathrm{X}_{2}\right)$ correlated with User Satisfaction ( $\left.\mathrm{Y}_{2}\right)$ through Service Quality ( $\left.\mathrm{Y}_{1}\right)$ as Mediator. It can also be seen from table 4.9 above which applied PLS method that the indirect effect of Academic Information System Application Effectiveness $\left(\mathrm{X}_{2}\right)$ correlated with User Satisfaction $\left(\mathrm{Y}_{2}\right)$ through Service Quality $\left(\mathrm{Y}_{1}\right)$ as Mediator reached $\mathrm{r}=0.175, \mathrm{t}_{\mathrm{cal}}=0.964$, and $\mathrm{P}_{\mathrm{value}}=0.335$. Therefore, it can be said that this correlation was not significant. This can also be proven by $\mathrm{t}_{\text {cal }}<\mathrm{t}_{\text {table }}$ (for $\mathrm{n}=90, \alpha=0.05$, gained table $=1.98$ ). As well as the $P_{\text {value }}$ of $0.335>\alpha=0.05$. However, the contribution of 0.175 of Service Quality indicated that Service Satisfaction was less positive and insignificant, proven by statistical test in which $t_{\text {cal }}<T_{\text {table }}=1.413<1.98$ and $P_{\text {value }}>0.5=0.158>0.05$. While Academic Information System Application Effectivenss and Digital Literacy achieved significant result, it was proven by statistical test result of $t_{\text {cal }}>T_{\text {table }}=2.776>1.98$ and $\left.\mathrm{P}_{\text {value }}<0.05=0.006<0.05\right)$.

The effectivenss and satisfaction level in giving service to students hit positive result but less significant since the statistical test of trustee level showed that $0.027<1.98$ dan $0.978>0.05$. Meanwhile, students' level of satisfaction in receiving service at Muhammadiyah University of Jakarta obtained the results of $(69.969>1.98$ and $0.000<0.05)$. The Effectiveness of Academic Information System Application and Digital Literacy to improve service quality to students of Muhammadiyah University of Jakarta hit significant results of $2.803>1.98$ and $0.005<0.05$. While the effectiveness of academic information system application through service quality showed positive result but not significant $(0.964<1.98$ dan $0.335>0.05)$.

\section{Conclusion}

Based on the analysis results of the data, it can be concluded that thise research study was positive and significant in which all variables influence each other as follows:

1. The effectiveness of Academic Information System, Digital Literacy, and service quality were positive and significant in which $t$-test $(2.776)>t_{\text {table }}(1.98)$ and $P_{\text {value }}$ of $0.006<0.05$.

2. The efforts to improve service quality and students' service satisfaction was also positive and significant proven from statistical test in which $\mathrm{t}_{\text {cal }}>\mathrm{t}_{\text {table }}$ and $\mathrm{P}_{\text {value }}<0.05$, namely $69.969>1.98$ dan $0.000<0.05$.

3. Service quality and digital literacy correlated with students' service satisfaction positively and significantly in which the statistical test revealed the results of 2.803 sebagai $t_{\text {cal }}>$ $\mathrm{tt}_{\text {able }}=1.98$ and $\mathrm{P}_{\text {value }}=0.005<0.05$. 


\section{References}

Adityar. (2017). Pengaruh Literasi Digital Terhadap Perilaku Internet Berisiko di Kalangan Siswa SMA, dan MA di Kota Makassar. Tesis. Program Pascasarjana Fakultas Ilmu Sosial Dan Ilmu Politik Universitas Hasanuddin Makassar. Indonesia.

Agus, D. (2012). Mewujudkan Good Governance Melalui Pelayanan Publik, Penerbit: Gadjah Mada Press. Yogyakarta. Indonesia.

Arikunto, S. (2011). Prosedur Penelitian suatu Pendekatan Praktik. Penerbit: Rineka Cipta. Jakarta. Indonesia.

Azhar, S. (2013). Sistem Informasi Akuntansi. Penerbit: Lingga Jaya. Bandung. Indonesia.

Cornell University. (2009). Laptop Ergonomics- 5 Tips for Using a Laptop Computer.

Davies, S. (2015). Spotlight on digital capabilities, www.digitalcapability.com

Ernia. E. E. (2008). Strategy Frameworkfor Promoting ICT Leteracy in The Asia-Pacific Region, Bangkok:UNESCO Bangkok, Asia and Pacific Regional Bureau for Education.eLC Research Paper Series. ISSUE 5.Communication \& Learning in the Digital Age ISSN 2013-7966. eLC Research Paper Series, 5, 14-25.

Fandy Tjiptono dan Gregorius Chandra, (2015). Service, Quality Satisfaction, Penerbit: Andi Offset. Yogyakarta. Indonesia.

Fandy, T.(2014). Manajemen Jasa, Penerbit: Andi Offset. Yogyakarta. Indonesia.

Fandy, T. (2009). Prinsip-Prinsip Total Quality Service, Penerbit: Andi Offset. Yogyakarta. Indonesia.

Freddy, R. (2004). The Power of Brand, Penerbit: PT. Gramedia Pustaka Utama. Jakarta. Indonesia.

Ghozali, Imam, (2011), Structural Equation Modeling Metode Alternatif Dengan Partial Least Square (PLS), Badan Penerbit Universitas Diponegoro. Semarang. Indonesia.

Harbani, P. (2011). Teori Administrasi Publik, Penerbit: CV. Alfabeta. Bandung. Indonesia. diakses pada tanggal: 15 Januari 2020, pukul 10:51 WIB).

Katz I. R., \& Macklin, A. S. (2008). Information and Communication Technology (ICT) Literacy: Integration and Assessment in Higher Education. Systemics, Cybernetics, and Informatic. Journal.

Kementerian Pendidikan dan Kebudayaan.2017. Materi Pendukung Literasi Digital. Jakarta 2017.

Murray, D. E. (2005). Technologies for L2 literacy. ARAL, 25, 188b-2001. Nani Pratiwi. Peran Literasi Digital Terhadap Minat Bersastra Pengguna Media Sosial. Jurnal. Prodi Pendidikan Bahasa dan Sastra Indonesia, Pascasarjana Universitas Negeri Yogyakarta.

Peter C. V., Jenny, van D. \& Matilda, D. (2005). Customer Value Management: An Overview 
and Research Agenda. Marketing JRM 2/2007.

Philip Kotler dan Kevin Lane Keller, (2009). Manajemen Pemasaran, Penerbit: Erlangga. Jakarta. Indonesia.

Podhisita, C. (2004). Theoritical Terminological, and Philosophical Issues in Qualitative Research, Qualitative Research Methods. Journal.

Rambat, L. (2006). Manajemen Pemasaran Jasa, Penerbit: PT. Salemba Empat. Jakarta. Indonesia.

Ratminto dan A. S.W. (2012). Manajemen Pelayanan, Penerbit: Pustaka Pelajar. Yogyakarta. Indonesia.

Said S. Al-G., \& Malcolm, K. (1999). Attitudes, satisfaction and usage: factors contributing to each in the acceptance of information technology. Journal. Behaviour \& Information Technology, 18(4). https://doi.org/10.1080/014492999119020

Sugiyono, (2015). Metode Penelitian Kuantitatif dan Kualitatif. Penerbit: CV.Alfabeta. Bandung. Indonesia.

Sujadi, K. (2014). Pengaruh Kualitas Layanan Terhadap Kepuasan Mahasiswa Program Pascasarjana Magister Manajemen STIE Abi Surabaya. Jurnal Bisnis, Manajemen \& Perbankan 1 (2) September 2014. https://doi.org/10.21070/jbmp.v1i2.268

Surjadi, (2012). Pengembangan Kinerja Pelayanan Publik, Penerbit: PT. Refika Aditama. Bandung. Indonesia.

Tony, W.(2011). Manajemen Kualitas Jasa, Penerbit: PT. Indeks. Jakarta. Indonesia.

VA, Z., \& Mary, J. B. (2016). Service Marketing. Terjemahan Singapore: Mc Graw-Hill Companies Inc.

Wheeler, S. (2012). Digital Literacies for Engagement in Emerging Online Cultures. Plymouth University United Kingdom.

Widhiarso, W. (2004). Teori dan Praktek Pemodelan SEM. Makalah Pelatihan SEM. Fakultas Psikologi. Yogyakarta: Universitas Gadjah Mada. Indonesia.

Yakub, (2012). Pengantar Sistem Informasi. Penerbit: Graha Ilmu. Yogyakarta. Indonesia.

\section{Copyright Disclaimer}

Copyright for this article is retained by the author(s), with first publication rights granted to the journal.

This is an open-access article distributed under the terms and conditions of the Creative Commons Attribution license (http://creativecommons.org/licenses/by/4.0/). 